\title{
What We've Learned from 2.5 Years of Early Market Fuel Cell Operation
}

J. Kurtz, S. Sprik, T. Ramsden, G. Saur, C. Ainscough

\section{November 6, 2012}

\author{
NREL/PR-5600-57759
}




\section{Objectives - Relevance}

Assess the technology status in real world operations, establish performance baselines, report on fuel cell and hydrogen technology, and support market growth by evaluating performance relevant to the markets' value proposition.

- Assess Technology

- Independent technology assessment in real world operation conditions

- Focused on fuel cell system and hydrogen infrastructure: performance, operation, and safety

- Leverage data processing and analysis capabilities developed under the fuel cell vehicle Learning Demonstration project

- Material handling equipment, backup power, portable power, and stationary power

- Support Market Growth

- Analyses and results relevant to the markets' value proposition

- Reporting on technology status to fuel cell and hydrogen communities and other key stakeholders like end users 


\section{Backup Power CDP Count and Category}

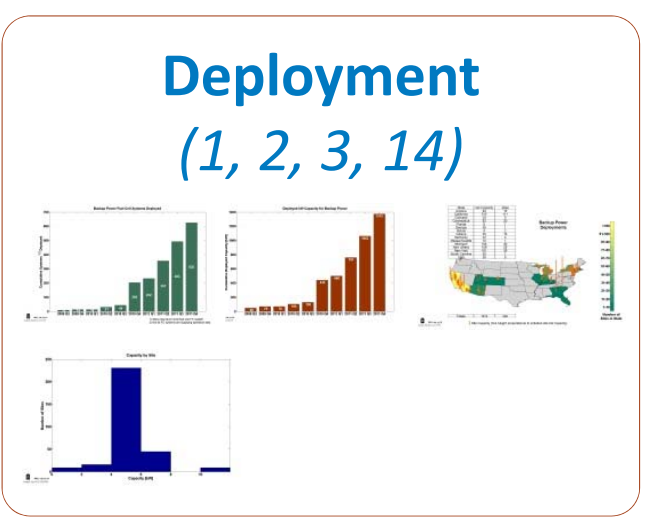

Infra. Operation

(6)

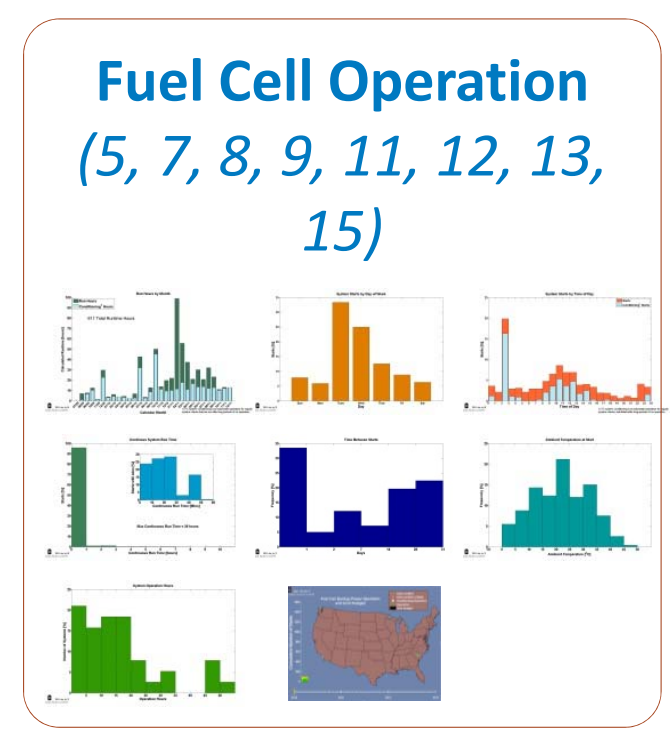

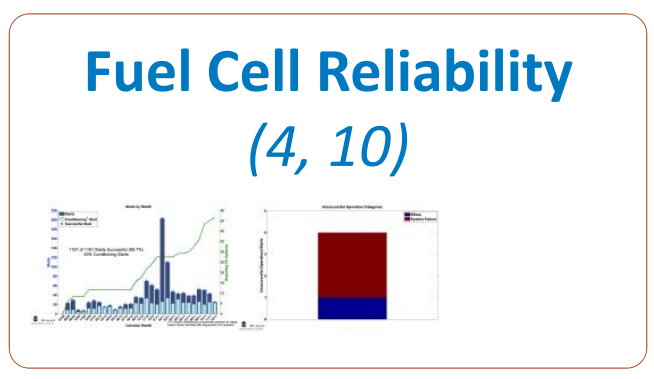




\section{Reliability: 99.5\% Successful Starts}

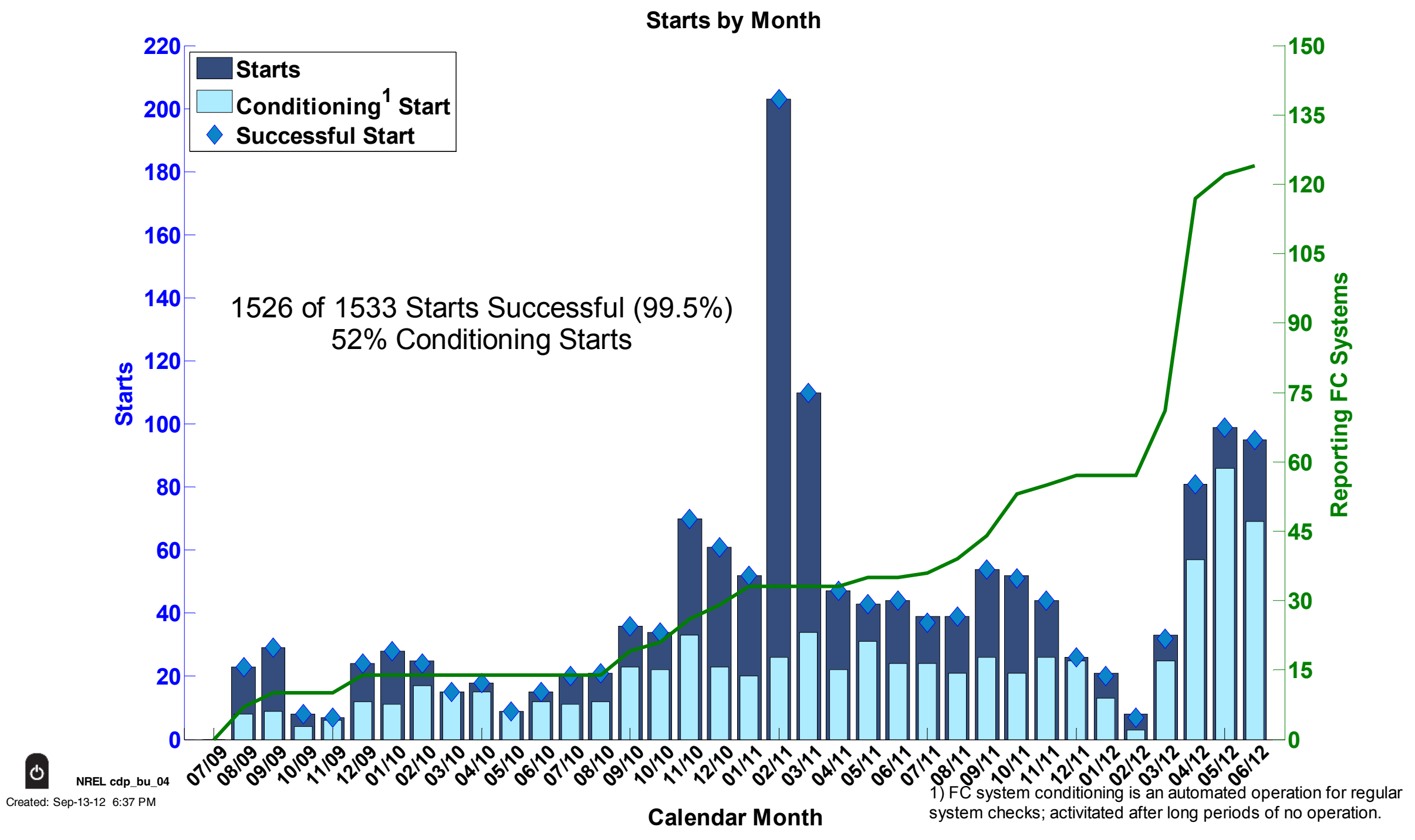




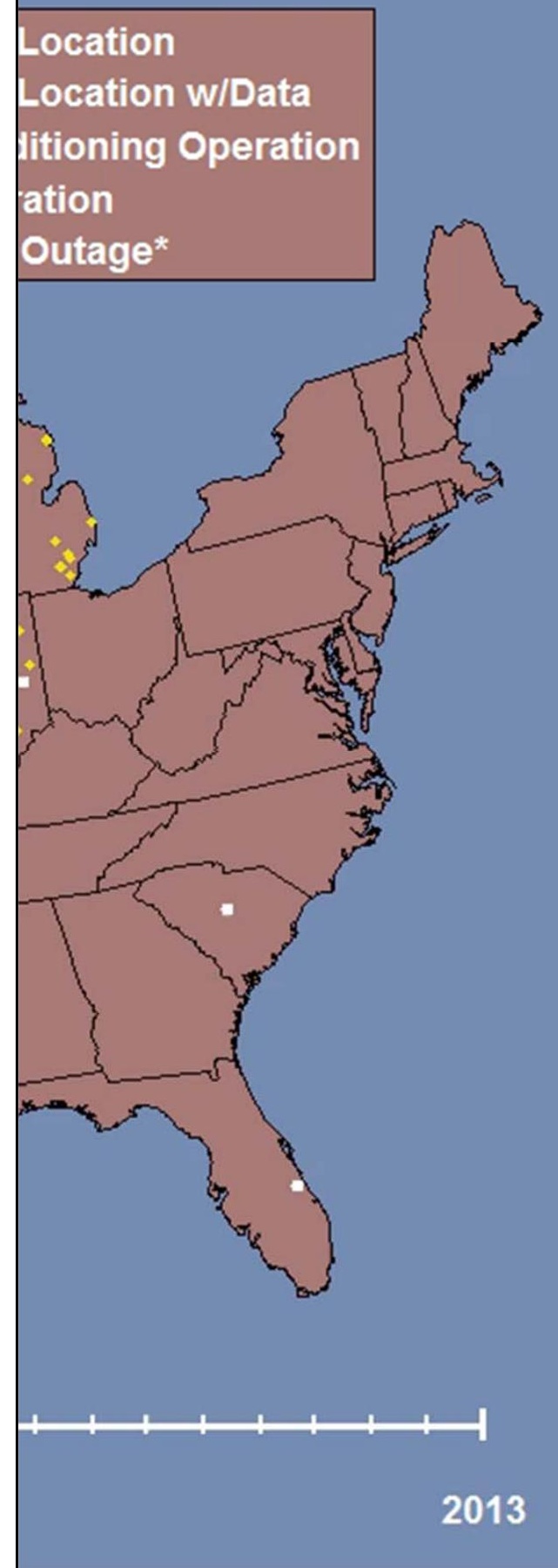




\section{Cost of Ownership: Backup Power}

Gathering data on:

- Site Description

- System Description

- System Requirements

- Capital Cost

- Operating \& Maintenance Cost

- Operating Lifetime for fuel cells, batteries, and generators

\begin{tabular}{|l|c|c|c|}
\hline & Fuel Cell* & Diesel & Battery \\
\hline Reliability & + & $\mathbf{0}$ & + \\
\hline Capital Cost (\$/kW) & - & + & ++ \\
\hline Extended Run Time & ++ & ++ & -- \\
\hline Emissions & ++ & - & ++ \\
\hline Noise & + & + & ++ \\
\hline Environmental & $\sim$ & - & $\sim$ \\
\hline Weight & + & - & - \\
\hline Efficiency & + & - & ++ \\
\hline Annual Fuel Cost & + & - & ++ \\
\hline Annual Maintenance Cost & + & - & ++ \\
\hline Maintenance Frequency & ++ & - & $?$ \\
\hline Refurbishment & + & + & -- \\
\hline Conditioning Tests & + & - & $\sim$ \\
\hline Operation Lifetime & + & ++ & -- \\
\hline
\end{tabular}

*Tax credit $\$ 3,000 / \mathrm{kW}$ or $30 \%$ total 


\section{MHE Result Categories}

Deployment \& Site Overview $(1,40)$ ull

\section{Fuel Cell Operation}

I-. $(2,7,8,11,15$, II:

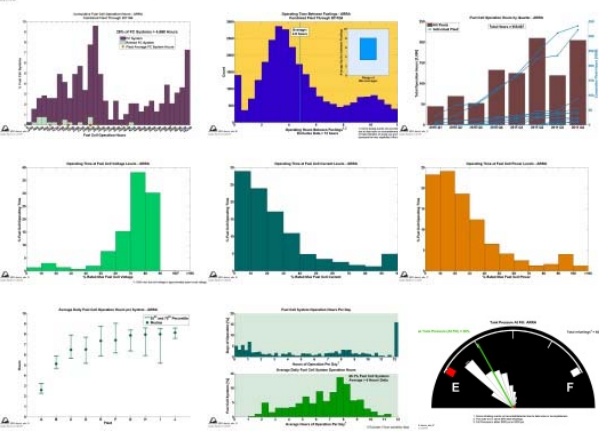

Fuel Cell Safety

$(26,27,53,56,57)$

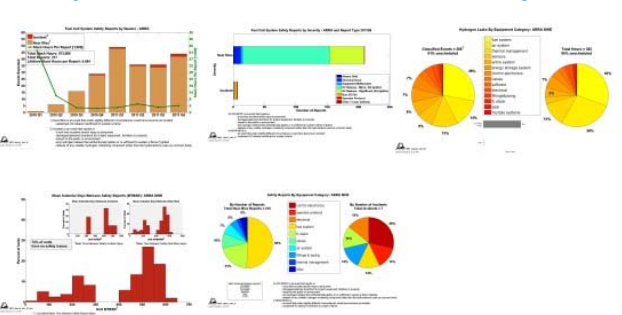

Infra. Operation

$(3,4,5,6,9,10,21$,

$22,35,37,42,62$ )
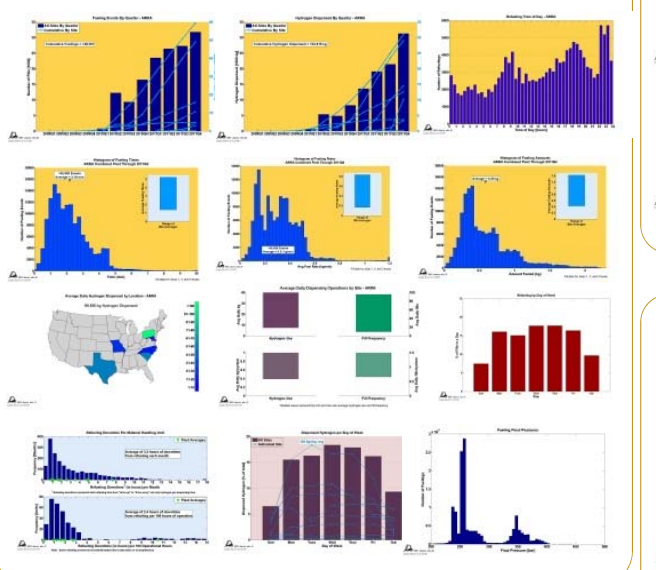

Infra. Safety

$(25,41,46,51,55)$

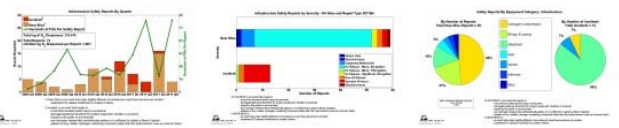

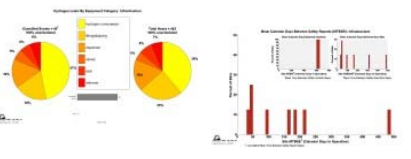

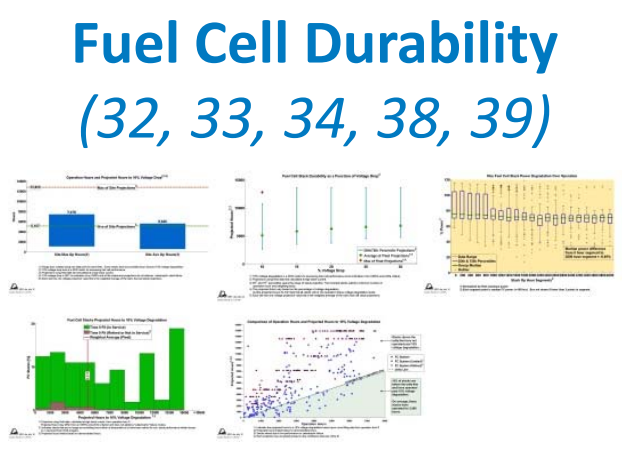

FC Maintenance

$(12,13,14,43,54,61)$
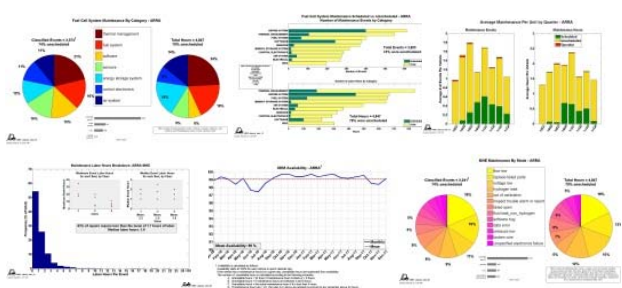

Infra. Maintenance

$(18,19,20,44,47,52)$

- D

$+400$
Infra. Reliability

$(45,48,49,50)$
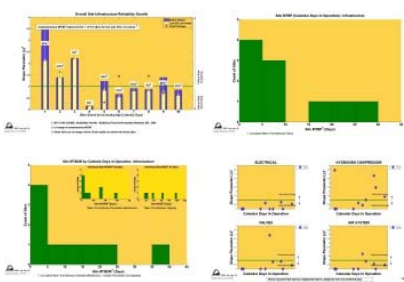

Fuel Cell Reliability

$(28,29,30,31)$
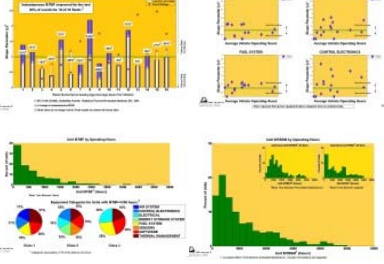

Cost of Ownership $(58,59,60,64)$

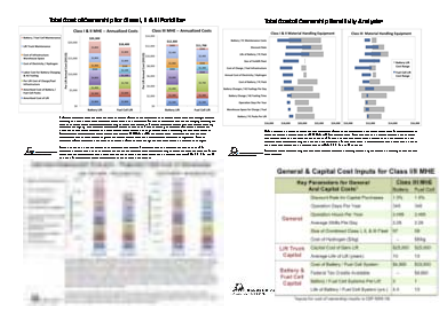




\section{MHE Operation Status}

\begin{tabular}{|c|c|c|}
\hline \multicolumn{2}{|c|}{ Key Operation Metric } & $\begin{array}{c}\text { CDPARRA- } \\
\text { MHE-\# }\end{array}$ \\
\hline $\begin{array}{c}\text { Units in Operation } \\
\text { (100 Class 1,62 Class 2, 172 class 3) }\end{array}$ & $490^{*}$ & 01 \\
\hline Hours Accumulated & $\begin{array}{c}1,248,384 \\
\mathrm{hrs}^{*}\end{array}$ & 11 \\
\hline $25 \%$ of FC Systems & $>5,260 \mathrm{hrs}^{*}$ & 02 \\
\hline $\begin{array}{c}\text { FC Systems Average } \\
>6 \text { hours Daily }\end{array}$ & $66 \%{ }^{*}$ & 24 \\
\hline Hydrogen Dispensed & $141,500 \mathrm{~kg}^{*}$ & 04 \\
\hline Hydrogen Fills & $197,991^{*}$ & 03 \\
\hline Average Fill Amount & $0.6 \mathrm{~kg}^{*} / \mathrm{fill}^{*}$ & 10 \\
\hline Average Fill Time & $2.3 \mathrm{~min}^{*} \mathrm{fill}^{*}$ & 06 \\
\hline $\begin{array}{c}\text { Average Op Time } \\
\text { between Fill }\end{array}$ & $4.7 \mathrm{hrs}^{*}$ & 08 \\
\hline
\end{tabular}

Class I

Class II

Class III

Height proportional to units deployed

The majority of sites have delivered liquid hydrogen. Two of the eight sites are greenfield sites. Four sites have more than one class of MHE in operation.

*Through June 2012 


\section{Annualized Total Cost of Ownership per Unit Identifies Key Cost Advantages are Dependent on Deployment Size}

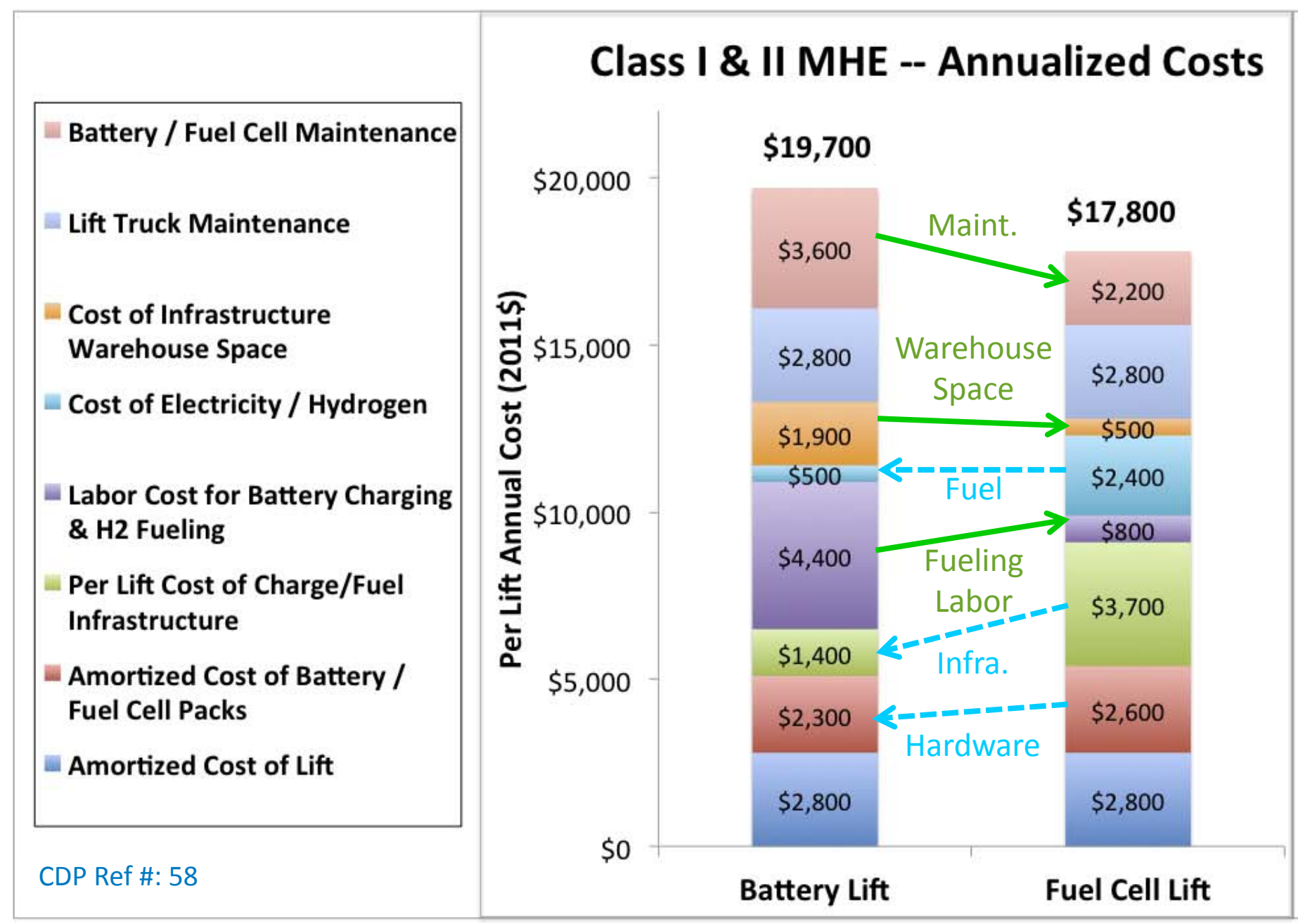

Analysis inputs are averages per category, some key inputs are:

- 58 FC lifts

- 333 days per year, 2.5 shifts per day $(2,100$ pedal hours per year)

- 3 min per hydrogen fill \& 10 min per battery change out

Class III Annualized Cost

- $\$ 11,700 \mathrm{FC}$

- $\$ 12,400$ Battery

Results assume replacements as needed and do not reflect technology generation improvements or other productivity improvements such as constant power, emissions, and cold environment. FC costs include current tax credit of $\$ 3,000 / \mathrm{kW}$ or $30 \%$ of purchase price. Data source: ARRA and DLA project partner questionnaire and fuel cell performance data. 


\section{Durability - Fuel Cell Voltage Degradation}

The average projected hours to $10 \%$ voltage degradation is 5,500 hours with $\sim 35 \%$ of stacks having a projection $>10,500$ hours.

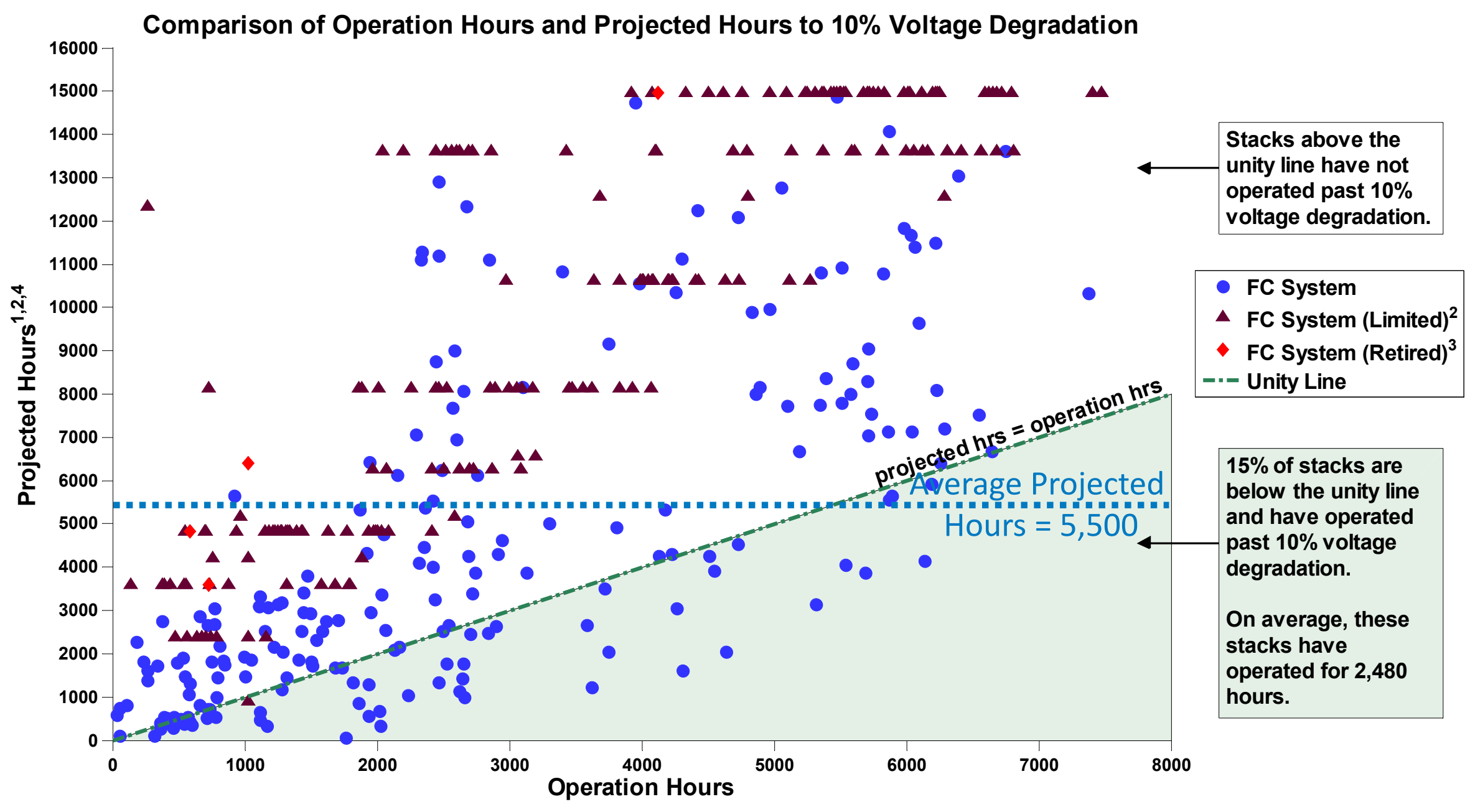




\section{Safety}

\section{MHE}

Majority of safety reports (217) are minor hydrogen leaks $(4,480$ stack hours per report)

\section{By Number of Incidents}

Total Incidents $=7$

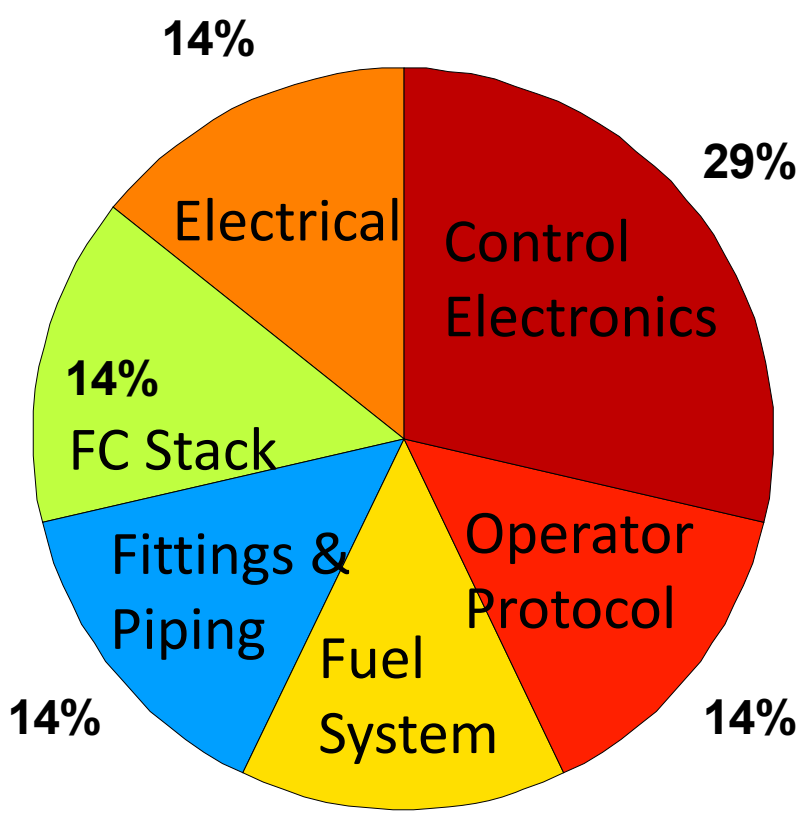

$14 \%$

\section{Infrastructure}

Majority of safety reports (76) are hydrogen leaks primarily from the hydrogen compressor and plumbing $(2,155 \mathrm{~kg}$ dispensed per report)

By Number of Incidents

Total Incidents $=16$

$6 \%$

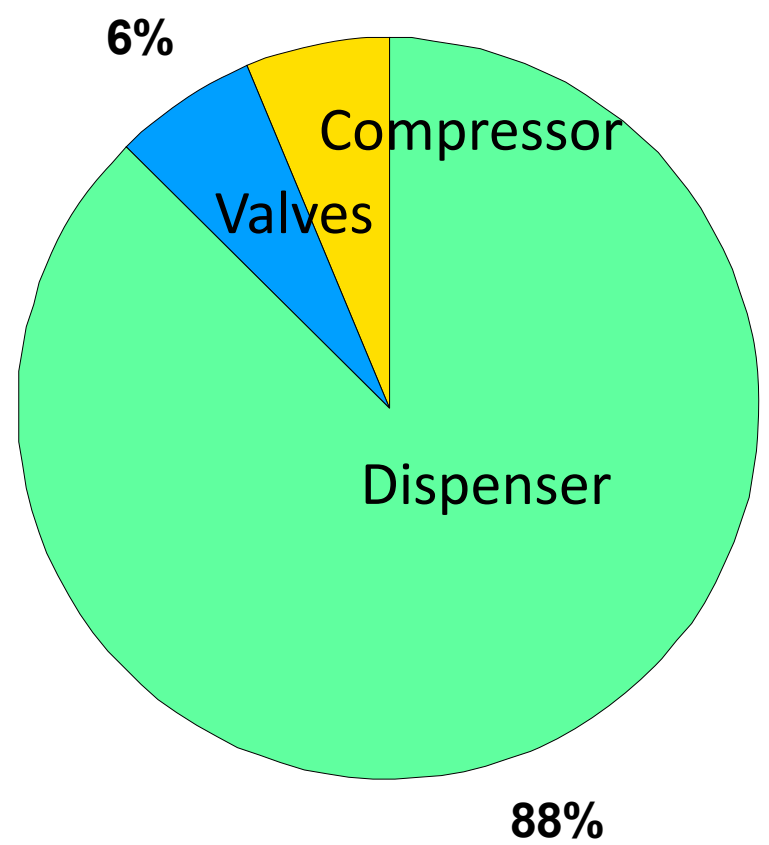




\section{Reliability - Fuel Cell System}

Unit MTBF by Operating Hours

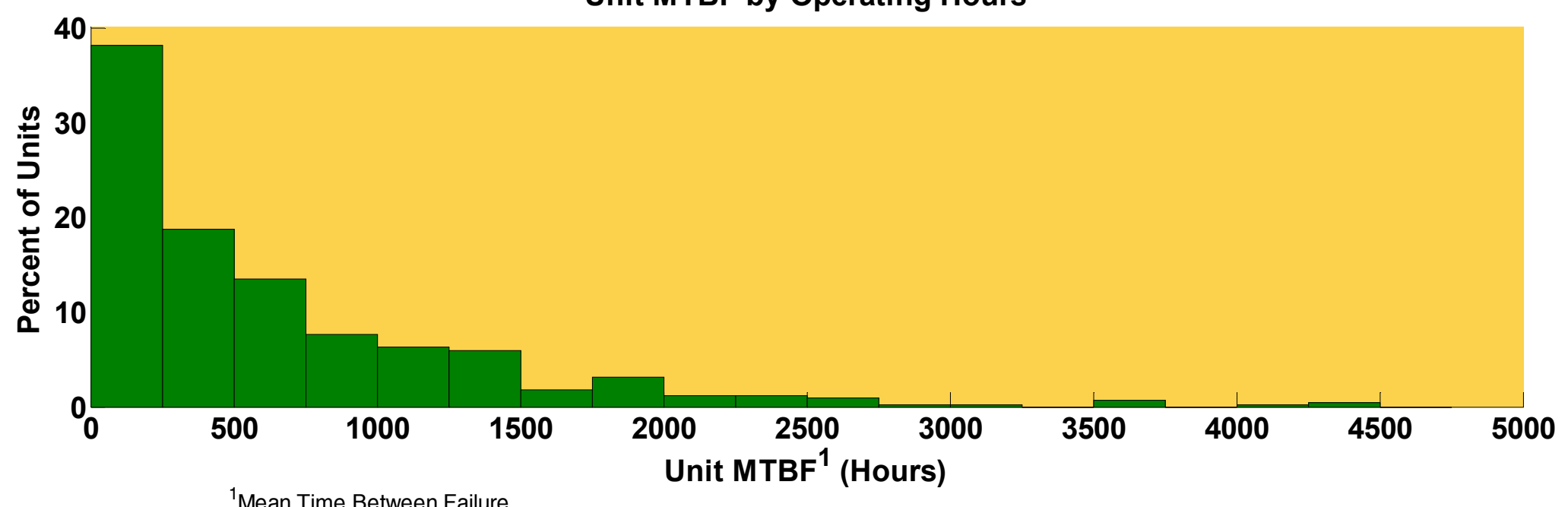

Mean Time Between Failure

Equipment Categories for Units with MTBF $<=250$ hours. $^{2}$

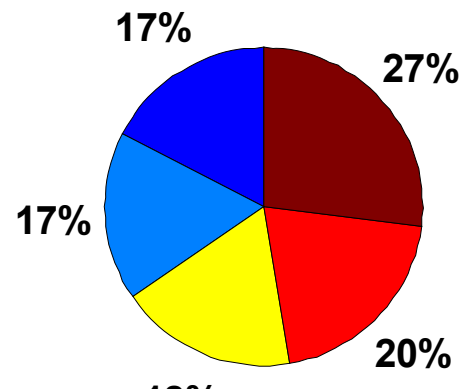

$18 \%$

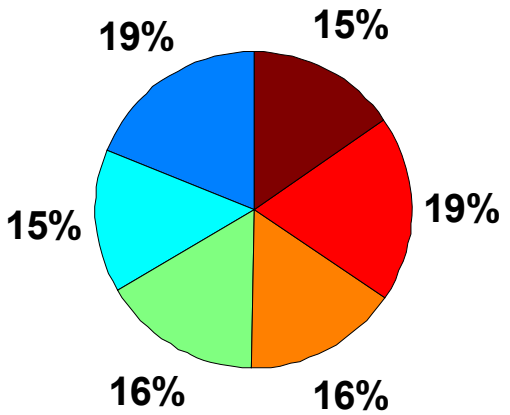

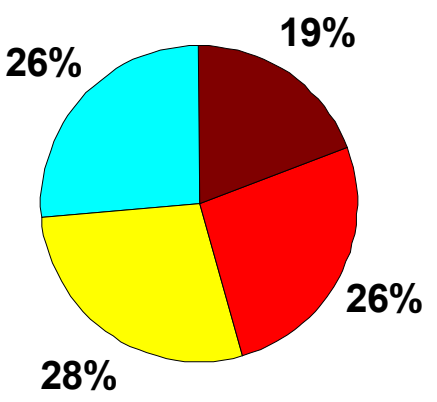

Class 3

AIR SYSTEM
CONTROL ELECTRONICS
ELECTRICAL
ENERGY STORAGE SYSTEM
FUEL SYSTEM
SENSORS
SOFTWARE
THERMAL MANAGEMENT

AIR SYSTEM CONTROL ELECTRONICS ELECTRICAL ENERGY STORAGE SYSTEM FUEL SYSTEM SENSORS

THERMAL MANAGEMENT $\int_{\text {S-od nReL cdp mhe } 30}$ Created: Mar-26-12 4:17 PM
Class 2

Class 1

${ }^{2}$ Categories representing $<10 \%$ of the total are not shown 


\section{Reliability - Infrastructure}

Site M TBF (Calendar Days In Operation): Infrastructure

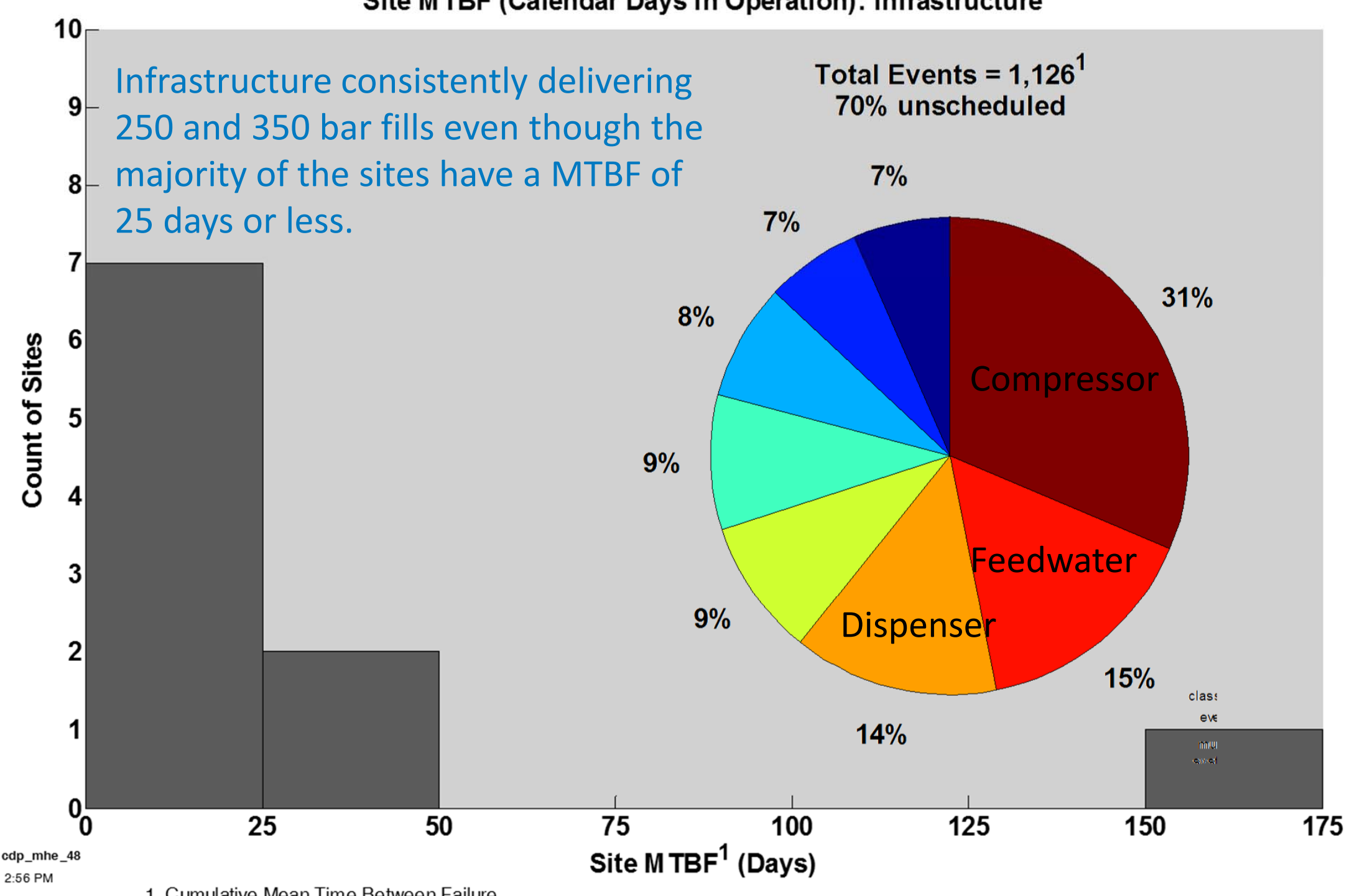

1. Cumulative Mean Time Between Failure 


\section{Capabilities - Infrastructure}

Number of Fuelings Per Hour - ARRA

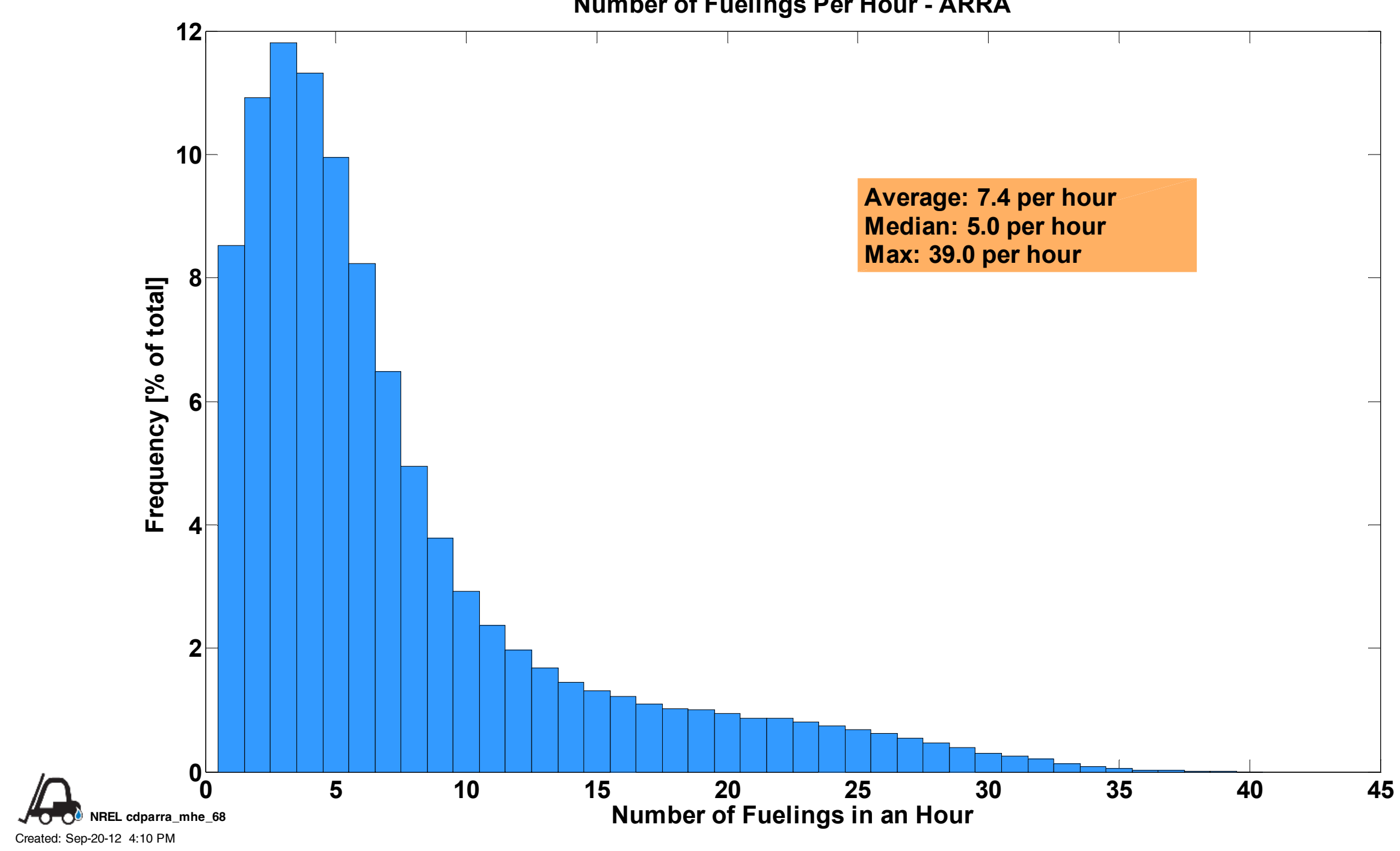




\section{Capabilities - Infrastructure}
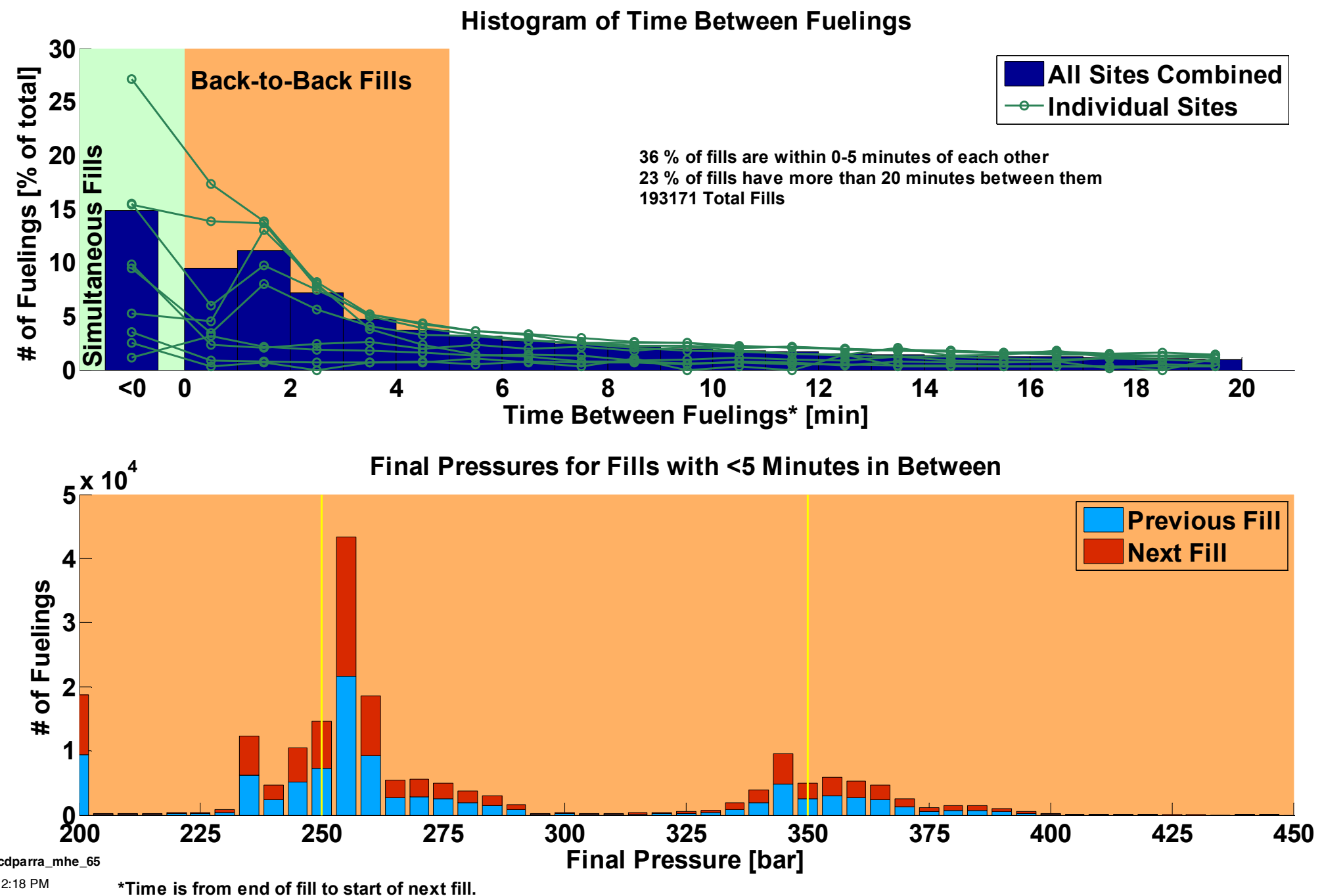


\section{Technical Summary - What We've Learned}

0

BACKUP POWER

\section{用} Fuel Cell Material Handling Equipment

- Operating with an average availability of $98 \%$ at 8 end-user facilities.

- Most systems operate at least 6 hours a day.

- Cost of ownership comparison between fuel cell and battery MHE indicate significant cost savings cost for refueling labor and infrastructure space but much greater cost for hydrogen infrastructure and fuel.
Aggregated data showcases performance over the last two years in MHE and backup power.

Performance results address a need for published results on the technology status.

Data analyses develop as systems operate and based on the key performance areas in the markets. 


\section{http://www.nrel.gov/hydrogen/proj fc market demo.html}

\section{INREL}
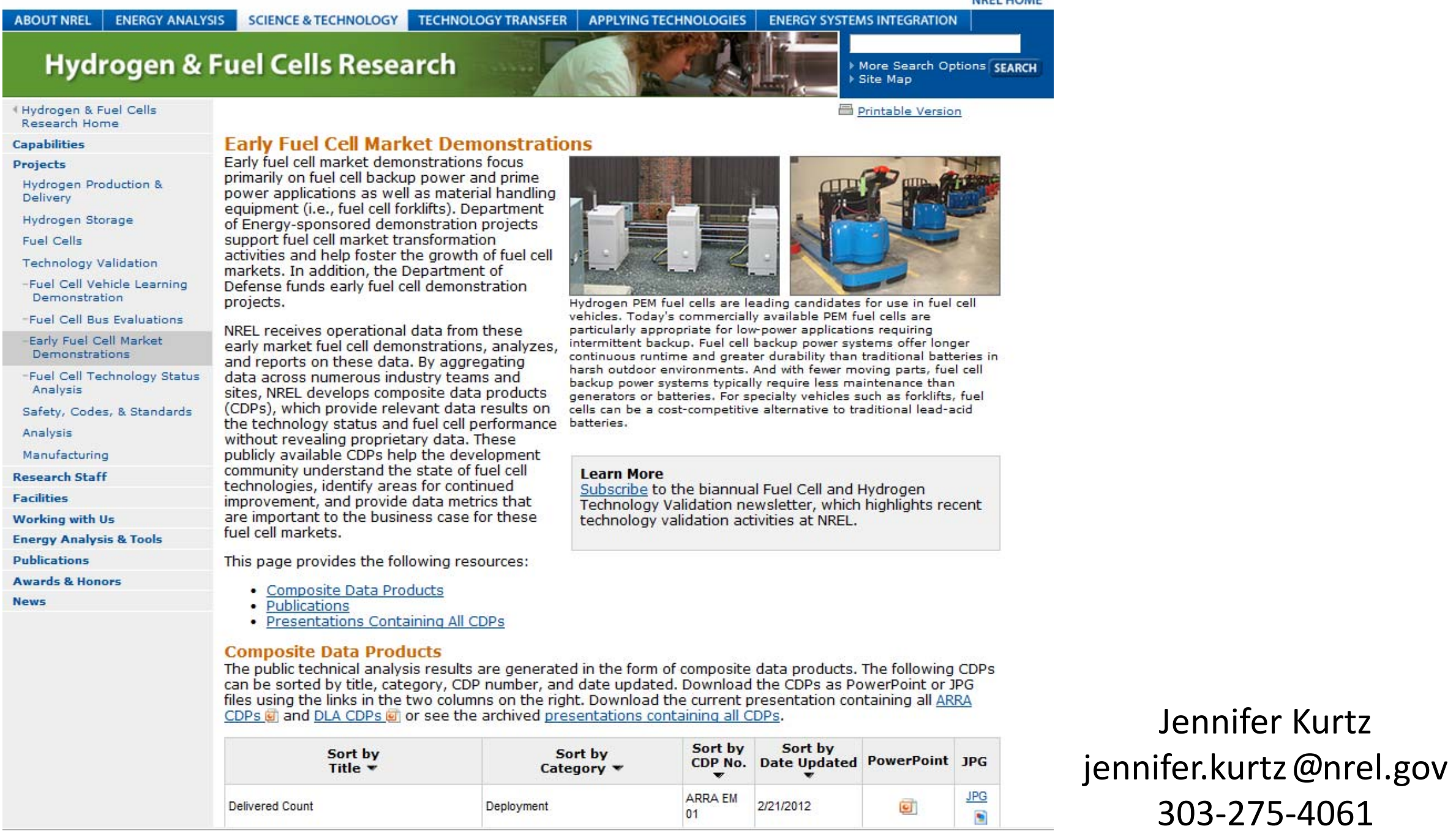

NREL receives operational data from these early market fuel cell demonstrations, analyzes, and reports on these data. By aggregating data across numerous industry teams and sites, NREL develops composite data products (CDPS), which provide relevant data results on the technology status and fuel cell performance

without revealing proprietary data. These publicly available CDPs help the development community understand the state of fuel cell technologies, identify areas for continued improvement, and provide data metrics that are important to the business case for these fuel cell markets. Hydrogen PEM fuel cells are leading candidates for use in fuel cell particularly appropriate for low-power applications requiring intermittent backup. Fuel cell backup power systems offer longer continuous runtime and greater durability than traditional batteries in harsh outdoor environments. And with fewer moving parts, fuel cell backup power systems typically require less maintenance than cells can be a cost-competitive alternative to traditional lead-acid batteries.

\section{Learn More}

Subscribe to the biannual Fuel Cell and Hydrogen

Technology Validation newsletter, which highlights recent technology validation activities at NREL.

\section{- Composite Data Products}

- Publications

Composite Data Products

The public technical analysis results are generated in the form of composite data products. The following CDPs can be sorted by title, category, CDP number, and date updated. Download the CDPS as PowerPoint or JPG files using the links in the two columns on the right. Download the current presentation containing all ARRA CDPS (6) and DLA CDPS 60 or see the archived presentations containing all CDPS.

\begin{tabular}{|l|l|l|l|l|}
\hline $\begin{array}{l}\text { Sort by } \\
\text { Title }\end{array}$ & $\begin{array}{c}\text { Sort by } \\
\text { Category }\end{array}$ & $\begin{array}{c}\text { Sort by } \\
\text { CDP No. }\end{array}$ & $\begin{array}{c}\text { Sort by } \\
\text { Date Updated PowerPoint }\end{array}$ & JPG \\
\hline Delivered Count & Deployment & $\begin{array}{l}\text { ARRA EM } \\
01\end{array}$ & $2 / 21 / 2012$ & \\
\hline
\end{tabular}

Jennifer Kurtz jennifer.kurtz@nrel.gov 303-275-4061 